\title{
Стан антиоксидантної системи захисту при експериментальному перитоніті на тлі цукрового діабету
}

\begin{abstract}
Мета роботи: вивчити стан антиоксидантної системи захисту в організмі піддослідних тварин при змодельованому гострому поширеному перитоніті на тлі цукрового діабету порівняно із тваринами з експериментальним гострим поширеним перитонітом.

Матеріали і методи. У експерименті використано 56 білих щурів. Цукровий діабет у дослідних тварин моделювали шляхом внутрішньоочеревинного введення стрептозотоцину фірми “Sigmal” з розрахунку 7 мг на 100 г маси тварини, гострий поширений перитоніт - введенням 0,5 мл 10 \% профільтрованої калової суспензії в черевну порожнину. Визначали показники антиоксидантного статусу - супероксиддисмутазну активність плазми, каталазну активність плазми та печінки, відновлений глутатіон, церулоплазмін. Терміни спостереження: 1, 3, 7 доби від початку моделювання перитоніту. Для проведення досліджень використовували сироватку крові та гомогенат печінки.

Результати досліджень та їх обговорення. У результаті досліджень доведено, що при гострому поширеному перитоніті на тлі цукрового діабету більшою мірою виснажуються антиоксидантні ресурси захисту порівняно із групою тварин зі змодельованим гострим перитонітом. В основній групі встановлено статистично значуще зниження таких антиоксидантних показників, як церулоплазмін (на 1 добу - на 12,25 \%, на 3 добу - на 12,11 \%, на 7 добу - на 11,15 \%), відновлений глутатіон (на 1 добу - на 11,87 \%, на 3 добу - на 10,89 \%, на 7 добу - на 9,42 \%), супероксиддисмутазна активність плазми крові (на 1 добу - на 9,94 \%, на 3 добу - на 13,22 \%, на 7 добу - на 7,43 \%), каталазна активність печінки (на 1 добу - на 7,63 \%, на 3 добу - на 19,39 \%, на 7 добу - на 20,97 \%) порівняно із групою із змодельованим гострим поширеним перитонітом (р<0,05). У тварин із експериментальним гострим поширеним перитонітом на тлі цукрового діабету захисні антиоксидантні ресурси виснажувалися більшою мірою порівняно із тваринами із змодельованим гострим перитонітом. Встановлене пригнічення антиоксидантної системи захисту вказує на значне виснаження факторів захисту організму при гострому поширеному перитоніті на тлі цукрового діабету.
\end{abstract}

Ключові слова: гострий поширений перитоніт; цукровий діабет; антиоксидантна система.

Постановка проблеми і аналіз останніх досліджень та публікацій. Гострий поширений перитоніт (ГПП) дедалі частіше виникає у хворих із супутньою патологією, в результаті змінюються механізми його розвитку, погіршуються наслідки лікування i, як наслідок, висока летальність. Здебільшого це $є$ наслідком недостатнього вивчення патогенетичних механізмів, що задіяні при даній патології, зокрема швидко прогресуючої гіпоксії, порушення мікроциркуляції, активації процесів ліпопероксидації, зниження антиоксидантної активності клітин і тканин [1, 2, 3].

Складність вирішення вузлових аспектів діагностики та лікування ГПП пояснюється особливістю віку хворих, зниженням імунорезистентності організму, зростанням кількості резистентних до антибіотиків штамів мікроорганізмів, глибиною і ступенем вираженості метаболічних порушень у системі гомеостазу і незначною кількістю надійних та ефективних методів їх корекції. Багатофакторність і полікомпонентність розвитку патофізіологічних розладів в організмі і складні морфофункціональні зміни внутрішніх органів призводять до розвитку ускладнень, котрі є осно- вними причинами летальності при перитоніті. Нездатність захисних сил організму до локалізації інфекції і адекватного виведення токсинів внаслідок патогенетичних особливостей цукрового діабету (ЦД) зумовлює у цих хворих розвиток синдрому поліорганної недостатності. На сучасному етапі розвитку медицини невирішеною є проблема лікування хворих із ГПП на тлі цукрового діабету, пов'язана 3 високим ризиком виникнення гнійно-септичних ускладнень $[4,5]$.

Одним із основних положень усіх сучасних концепцій патогенезу різних захворювань, в тому числі і ГПП, є порушення структури клітинної мембрани, універсальним фактором пошкодження якої $є$ перекисне окиснення ліпідів (ПОЛ). Стаціонарний рівень вільнорадикального окиснення і ПОЛ в організмі підтримується завдяки активності ферментних і неферментних антиоксидантних систем (АОС) захисту. Початкові стадії процесу вільнорадикального окиснення контролюються супероксиддисмутазною (СОД) активністю, яка дезактивує супероксидний радикал і відповідно зменшує загальний токсичний ефект активних форм кисню. Пероксид водню, що утворюєть- 
ся при дисмутації супероксидного аніону, розкладає каталаза. Важливу роль в метаболізмі перекису водню відіграє каталаза, концентрація якої в клітині значна. Каталаза широко поширена в тканинах, i особливо висока її активність в еритроцитах [6, 7].

Проте донині до кінця не з'ясовані питання ролі активності антиоксидантових ферментів у патогенезі системних відхилень при ГПП, ускладненому ЦД. Різнонаправленість змін в організмі цих хворих вимагають розробки нових і вдосконалення відомих методів лікування.

Мета роботи: вивчити стан АОС захисту в організмі піддослідних тварин при змодельованому ГПП на тлі ЦД порівняно із тваринами з експериментальним ГПП.

Матеріали і методи. Експерименти виконано на базі Центральної науково-дослідної лабораторії Державного вищого навчального закладу “Тернопільський державний медичний університет імені І. Я. Горбачевського МОЗ України” (свідоцтво про атестацію № 000478 від 17.12.2007р.).

Під час досліджень використано 56 білих щурів, яких було поділено на три групи: основна група - 24 тварини із змодельованим ГПП на тлі ЦД; група порівняння - 24 тварини із змодельованим перитонітом; контрольна група - 8 інтактних тварин, яких утримували у стандартних умовах віварію. Усі порівнювані групи тварин були репрезентативні за масою, статтю та віком.

Експериментальний ЦД відтворювали шляхом внутрішньоочеревинного застосування стрептозотоцину натщесерце в дозі 60 мг/кг (фірми “Sigmal», який розчиняли в буферному натрієвоцитратному розчині рН 4,5). Дослідження вмісту глюкози здійснювали о $9^{00}$ за умов вільного доступу експериментальних тварин до їжі та води протягом нічного періоду часу. Впродовж всього періоду спостереження щурам вводили інсулін (02 ОД підшкірно два-пять разів на тиждень).

Через 2 тижні з моменту застосування стрептозотоцину в щурів із венозної крові, яку отримували із хвостової вени, визначали вміст глюкози і в подальших дослідженнях спостерігали тільки тих щурів, у яких вміст глюкози складав більше 300 мг/л. Тваринам контрольної групи замість стрептозотоцину вводили підшкірно стерильний 0,9 \% розчин натрію хлориду [8].

Вплив ЦД на перебіг ГПП вивчали на запропонованій В. А. Лазаренком та співавт. моделі [9]. Ця модель за етіологічними чинниками, клінічними проявами і фазністю перебігу подібна до аналогічного процесу в людини. На 14-ту добу після уведення стрептозотоцину тваринам основної групи вводили 10 \% профільтрованої калової суспензії в черевну порожнину дослідних щурів у дозі 0,5 мл на 100 г маси тіла. Щурам групи порівняння лише підшкірно вводили калову суспензію. Калову суспензію отримували шляхом змішування ізотонічного розчину і калу зі сліпої кишки 2-3 інтактних тварин, потім її двічі фільтрували через подвійний шар марлі. Одержану суспензію не пізніше ніж через 20 хв після приготування вводили інтактним щурам пункційним способом. Щоб уникнути пошкодження внутрішніх органів при введенні калової суспензії в черевну порожнину, тварин тримали вертикально, каудальним кінцем вгору. Методом пункції вентральної стінки в центрі середньої лінії живота, направляючи кінець голки по черзі у праве і ліве підребер’я, праву та ліву клубові ділянки, вводили однакову кількість калової суспензії.

Терміни спостереження - 1-ша, 3-тя і 7-ма доби від початку моделювання перитоніту. Для проведення досліджень використовували цільну кров та сироватку крові, а також гомогенат печінки.

Дане експериментальне дослідження проводили із дотриманням загальних правил і положень Європейської Конвенції із захисту хребетних тварин, які використовуються для дослідницьких та інших наукових цілей (Страсбург, 1986), Загальних етичних принципів експериментів на тваринах (Київ, 2001) та Закону України “Про захист тварин від жорстокої поведінки” (2006).

Про стан АOC захисту в різні терміни експерименту судили за рівнями СОД активності в плазмі крові, каталазної активності крові та печінки, відновленого глутатіону та церулоплазміну (ЦП) плазми крові.

СОД активність визначали на підставі здатності їі конкурувати з нітротетразолієм синім за супероксидні аніони, які утворюються внаслідок аеробної взаємодії відновленої форми НАДН 2 та феназинметасульфату. Ступінь блокування активності СОД визначали спектрометричним методом. За 1 ум. од. СОД активності приймали таку кількість ферменту, яка здатна пригнічувати відновлення нітротетразолію синього на 50 \%.

Каталазну активність визначали за методом, принцип якого полягає на здатності пероксиду водню утворювати з молібдатом амонію стійкий забарвлений комплекс. Досліджували плазму крові і тканину печінки, з якої на холоді готували 10 \% гомогенат на 0,05 М тріс-буфері (pH = 7,8). Реакцію розпочинали з додавання 0,1 мл плазми або гомогенату до 2 мл 0,03 \% розчину пероксиду водню. Паралельно готували холосту пробу, в яку замість досліджуваного матеріалу вносили 
0,1 мл дистильованої води. Через 10 хв реакцію зупиняли додаванням 1 мл 4 \% молібдату амонію. Інтенсивність забарвлення розчину вимірювали за допомогою спектрофотометричного методу [10].

Вміст відновленого глутатіону визначали за спектрофотометричним методом [11], який полягає в тому, що при взаємодії 5,5'-дитіобіс (2-нітробензойної) кислоти (реактив Елмана) з вільними SH-групами відновленого глутатіону відбувається утворення тіонітрофенильного аніону, кількість якого прямо пропорційна вмісту SH-груп.

Кількість церулоплазміну (ЦП) також визначали за спектрофотометричним методом [12]. Принцип методу: окиснення п-фенілендіаміну в присутності ЦП призводить до утворення забарвлених продуктів. Кількість ЦП прямо пропорційна інтенсивності забарвлення. Досліджували плазму крові. В пробірки вносили по 0,1 мл плазми. В контрольну пробірку додавали 1 мл 0,5 \% розчину гідроксиламіну солянокислого з метою інактивації ферменту. У всі пробірки додавали по 8 мл 0,4 М розчину ацетатного буферу $(\mathrm{pH}=$ 5,5) і по 1 мл п-фенілендіаміну. Пробірки закривали корками і витримували в термостаті при $37^{\circ} \mathrm{C}$ протягом години. Потім у кожну пробірку, крім контролю, додавали 1 мл гідроксиламіну солянокислого. Проби витримували 30 хв при $4{ }^{\circ} \mathrm{C}$ після чого визначали їх оптичну щільність проти контролю на спектрофотометрі.

Статистичну обробку цифрових даних здійснювали за допомогою програмного забезпечення Excel i STATISTICA з використанням параметричних і непараметричних методів оцінки отриманих даних. Для всіх показників розраховували значення середньої арифметичної вибірки (М), їі дисперсії і помилки середньої (m). Достовірність різниці значень між незалежними кількісними величинами визначали при нормальному розподілі за t-критерієм Стьюдента, в інших випадках - за допомогою U-критерію Манна-Уїтні (достовірними вважали відмінності при $\mathrm{p}<0,05)$.
Результати досліджень та ї обговорення. При дослідженні стану показників АОС у порівняльній групі тварин із змодельованим ГПП встановлено лінійне статистично значуще зменшення вмісту СОД активності залежно від збільшення терміну спостереження: на 9,87 \%, 18,97 \% та на 30,97 \% на 1, 3 та 7 доби відповідно (табл. 1) $(\mathrm{p}<0,05)$. Щодо каталазної активності в крові та печінці, то ії вміст статистично значуще зменшувався відносно термінів спостереження $(\mathrm{p}<0,05)$. Це можна пояснити тим, що каталаза є внутрішньоклітинним ферментом, яка у ранні терміни ураження активується в печінці з подальшим збільшенням її концентрації в плазмі крові.

Концентрація відновленого глутатіону в крові у тварин із змодельованим ГПП також статистично значуще спадала відповідно до збільшення терміну спостереження порівняно 3 інтактною групою: на 19,49 \%, 25,74 \% та на 29,78 \% на 1, 3 та 7 доби відповідно (p<0,05). Динаміка вмісту ЦП у плазмі крові протягом експерименту змінювалася аналогічно концентрації ферментативних представників АОС, тобто зменшувалася.

У тварин основної групи процеси АОС захисту виснажувалися більшою мірою порівняно із групою порівняння (табл. 2). СОД активність на 1 добу спостереження зменшилася на 12,83 \% відносно інтактної групи та на 9,94 \% порівняно із групою із змодельованим ГПП; на 3 добу СОД активність зменшилася на 29,68 \% та на 13,22 \%, а на 7 добу на 36,52 \% та на 7,43 \% відповідно ( $<0,05)$. Рівень каталазної активності в крові та печінці дослідних тварин із експериментальним ГПП на тлі ЦД зменшувався відносно збільшення термінів спостереження і був статистично значуще нижчим від такого показника групи із змодельованим ГПП (p<0,05).

Вміст відновленого глутатіону крові у тварин основної групи лінійно спадав порівняно з інтактними тваринами: на 29,04 \% і 11,87 \% - на 1 добу; на 33,82 \% і 10,89 \% - на 3 добу; на 36,40 \% і 9,42 \% - на 7 добу відповідно, і був статистич-

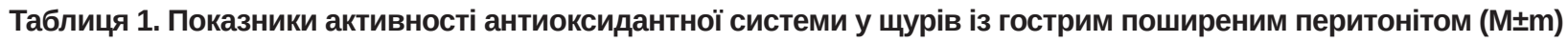

\begin{tabular}{||l|c|c|c|c||}
\hline \multirow{2}{*}{\multicolumn{1}{|c|}{ Показник }} & \multicolumn{4}{|c||}{ Групи піддослідних тварин } \\
\cline { 2 - 5 } & \multirow{2}{*}{$\begin{array}{c}\text { Iнтактні } \\
(\mathrm{n}=8)\end{array}$} & \multicolumn{2}{c||}{ Тварини із гострим перитонітом (n=24) } \\
\cline { 3 - 6 } & 1 доба (n=8) & 3 доба $(\mathrm{n}=8)$ & 7 доба $(\mathrm{n}=8)$ \\
\hline СОД активність, ум. од. & $57,15 \pm 1,65$ & $51,51 \pm 1,08 \#$ & $46,31 \pm 0,93 \#$ & $39,45 \pm 0,63 \#$ \\
\hline Каталазна активність крові, мкат/л & $0,18 \pm 0,01$ & $0,27 \pm 0,01 \#$ & $0,20 \pm 0,01 \#$ & $0,19 \pm 0,01 \#$ \\
\hline Каталазна активність печінки, мкат· ${ }^{-1}$ & $3,99 \pm 0,08$ & $5,34 \pm 0,11 \#$ & $5,21 \pm 0,11 \#$ & $4,19 \pm 0,06 \#$ \\
\hline Відновлений глутатіон у крові, мМ/л & $2,72 \pm 0,01$ & $2,19 \pm 0,02 \#$ & $2,02 \pm 0,05 \#$ & $1,91 \pm 0,04 \#$ \\
\hline ЦП, г/л & $0,23 \pm 0,02$ & $0,36 \pm 0,01 \#$ & $0,29 \pm 0,01 \#$ & $0,24 \pm 0,01 \#$ \\
\hline \hline
\end{tabular}

Примітка: \# - достовірність різниці стосовно таких показників групи інтактних тварин. 
Таблиця 2. Показники активності антиоксидантної системи у крові щурів із гострим поширеним перитонітом на тлі цукрового діабету $(\mathrm{M} \pm \mathrm{m})$

\begin{tabular}{|c|c|c|c|c|}
\hline \multirow[t]{3}{*}{ Показник } & \multicolumn{4}{|c|}{ Групи піддослідних тварин } \\
\hline & \multirow{2}{*}{$\begin{array}{l}\text { Інтактні } \\
(\mathrm{n}=8)\end{array}$} & \multicolumn{3}{|c|}{ Тварини із гострим перитонітом (n=24) } \\
\hline & & 1 доба (n=8) & 3 доба $(\mathrm{n}=8)$ & 7 доба $(\mathrm{n}=8)$ \\
\hline СОД активність, ум. од. & $57,15 \pm 1,65$ & $\begin{array}{l}46,39 \pm 0,84 \# \\
\quad * \mathrm{p}<0,05\end{array}$ & $\begin{array}{c}40,19 \pm 0,86 \# \\
* \mathrm{p}<0,05 \\
\# \# \mathrm{p}<0,05\end{array}$ & $\begin{array}{c}36,28 \pm 1,27 \# \\
* \mathrm{p}<0,05 \\
\# \# \mathrm{p}<0,05 \\
* * \mathrm{p}<0,05\end{array}$ \\
\hline $\begin{array}{l}\text { Каталазна активність } \\
\text { крові, мкат/л }\end{array}$ & $0,18 \pm 0,01$ & $\begin{array}{l}0,31 \pm 0,01 \# \\
\quad * \mathrm{p}<0,05\end{array}$ & $\begin{array}{c}0,24 \pm 0,01 \# \\
* \mathrm{p}<0,05 \\
\# \# \mathrm{p}<0,05\end{array}$ & $\begin{array}{c}0,23 \pm 0,01 \# \\
* \mathrm{p}<0,05 \\
\# \# \mathrm{p}<0,05 \\
* * \mathrm{p}<0,05\end{array}$ \\
\hline $\begin{array}{l}\text { Каталазна активність } \\
\text { печінки, мкат· } \Gamma^{-1}\end{array}$ & $3,99 \pm 0,08$ & $\begin{array}{l}6,46 \pm 0,12 \# \\
\quad * \mathrm{p}<0,05\end{array}$ & $\begin{array}{c}6,22 \pm 0,13 \# \\
* \mathrm{p}<0,05 \\
\# \# \mathrm{p}<0,05\end{array}$ & $\begin{array}{c}4,51 \pm 0,13 \# \\
* \mathrm{p}<0,05 \\
\# \# \mathrm{p}<0,05 \\
* * \mathrm{p}<0,05\end{array}$ \\
\hline $\begin{array}{l}\text { Відновлений глутатіон у } \\
\text { крові, мМ/л }\end{array}$ & $2,72 \pm 0,01$ & $\begin{array}{c}1,93 \pm 0,02 \# \\
{ }^{*} \mathrm{p}<0,05\end{array}$ & $\begin{array}{c}1,80 \pm 0,02 \# \\
* \mathrm{p}<0,05 \\
\# \# \mathrm{p}<0,05\end{array}$ & $\begin{array}{c}1,73 \pm 0,02 \# \\
* \mathrm{p}<0,05 \\
\# \# \mathrm{p}<0,05 \\
* * \mathrm{p}<0,05\end{array}$ \\
\hline ЦП, г/л & $0,23 \pm 0,02$ & $\begin{array}{l}0,41 \pm 0,01 \# \\
\quad * \mathrm{p}<0,05\end{array}$ & $\begin{array}{c}0,33 \pm 0,01 \# \\
* \mathrm{p}<0,05 \\
\# \# \mathrm{p}<0,05\end{array}$ & $\begin{array}{c}0,27 \pm 0,01 \# \\
* \mathrm{p}<0,05 \\
\# \# \mathrm{p}<0,05 \\
* * \mathrm{p}<0,05\end{array}$ \\
\hline
\end{tabular}

Примітки: 1. \# - достовірність різниці стосовно таких показників групи інтактних тварин;

2. * - достовірність різниці стосовно таких показників порівняльної групи;

3. \#\# - достовірність різниці стосовно таких показників групи тварин на 1 добу спостереження;

4. ** - достовірність різниці стосовно таких показників групи тварин на 3 добу спостереження.

но значуще нижчим від таких показників групи тварин із змодельованим ГПП ( $<<0,05)$. Вміст ЦП у тварин із змодельованим ГПП на тлі ЦД також зменшувався і був статистично значуще нижчим від такого показника порівняльної групи $(\mathrm{p}<0,05)$.

Отже, у тварин із експериментальним ГПП на тлі ЦД захисні ресурси АОС виснажувалися більшою мірою порівняно із тваринами із змодельованим ГПП.

Висновки. У тварин із ГПП на тлі ЦД суттєво виснажувалися ресурси антиоксидантного захисту, що підтверджено статистично значимо нижчими рівнями відновленого глутатіону, ЦП, СОД активності плазми крові та каталазної активності печінки порівняно із групою тварин із змодельованим ГПП. Виявлене пригнічення АОС захисту вказує на значне виснаження факторів захисту організму при ГПП на тлі ЦД.

Перспективи подальших досліджень передбачають вивчення взаємозалежності прооксидантної та антиоксидантної системи захисту при змодельованому гострому перитоніті на тлі ЦД.

\section{СПИСОК ЛІТЕРАТУРИ}

1. Дзюбановський I. Я. Синдром поліорганної недостатності та його корекція у хворих на гострий поширений перитоніт / І. Я. Дзюбановський, Б. О. Мігенько // Укр. журн. хірургії. 2009. - № 2. - С. 56-59.

2. Білик I. I. Гострий перитоніт як ускладнення гострого апендициту / I. І. Білик // Клін. та експеримент. патол. - 2016. - № 1 (43). - С. 187-189.

3. Гринчук Ф. В. Патогенетичні, клінічні і тактичні особливості при перитоніті та поєднаній патології / Ф. В. Гринчук //

Харківська хірургічна школа. - 2014. - № 6 (44). - С. 47-49. 4. Spirt M. J. Complicated intra-abdominal infections: a focus on appendicitis and diverticulitis / M. J. Spirt // Postgrad. Med. 2010. - Vol. 122, No. 1. - P. 39-51.

5. Kimura W. Problems and therapeutic strategy for emergen cy operation of the abdomen in the aged / W. Kimura, M. Mizutani, A. Fuse // Nippon Ronen Igakkai Zasshi. - 2014. - Vol. 41, No. 6. - P. 660-665.

6. Петросян Э. А. Состояние про- и антиоксидантной сис- 
тем крови при экспериментальном желчном перитоните / Э. А. Петросян, В. И. Сергиенко, А. А. Сухинин // Бюл. эксперим. биол. и мед. - 2015. - 139, № 1. - С. 19-21.

7. Blot S. Critical issues in the clinical management of complicated intraabdominal infections / S. Blot, J. J. De Waele // Drugs. 2015. - No. 65 (12). - P. 1611-1620.

8. Al-Malki A. L. Oat attenuation of hyperglycemia-induced retinal oxidative stress and NF-kB activation in streptozotocininduced diabetic rats / A. L. Al-Malki // Evidence-Based Complementary and Alternative Medicine. - 2013. Article ID 983923, p. 8. DOI: http://dx.doi.org/10.1155/2013/983923

9. Экспериментальная модель распространенного калового перитонита / В. А. Лазаренко, В. А. Липатов, Ю. Ю. Блинков, Д. В. Скориков // Человек и его здоровье. - 2008. - № 4. - С. $128-132$.

10. Андреева Л. И. Модификация метода определения перекисей липидов в тесте с тиобарбитуровой кислотой / Л. И. Андреева, Л. А. Кожемякин, А. А. Кишкун // Лаб. дело. - 1988. - № 11. - С. 41-43.

11. Горячковський О. М. Клінічна біохімія в лабораторній діагностиці : довідковий посібник / О. М. Горячковський. Одеса : Екологія, 2015. - 616 с.

12. Стальная И. Д. Современные методы в биохимии / И. Д. Стальная. - М. : Медицина, 1977. - С. 63-64.

\section{REFERENCES}

1. Dziubanovskyi, I.Ya. \& Mihenko, B.O. (2009). Syndrom poliorhannoi nedostatnosti ta yoho korektsiia u khvorykh na hostryi poshyrenyi perytonit [The syndrome of multiple organ failure and its correction in patients with acute common peritonitis]. Ukr. Zhurn. Khirurhii - Ukrainian Journal of Surgery, 2, 56-59 [in Ukrainian].

2. Bilyk, I.I. (2016). Hostryi perytonit yak uskladnennia hostroho apendytsytu [Acute peritonitis as a complication of acute appendicitis]. Klinichna ta eksperymentalna patolohiia-Clinical and Experimental Pathology, 1 (43), 187-189 [in Ukrainian].

3. Hrynchuk, F.V. (2014). Patohenetychni, klinichni i taktychni osoblyvosti pry perytoniti ta poiednanii patolohii [Pathogenetic, clinical and tactical features in peritonitis and combined pathology]. Kharkivska khirurhichna shkola - Kharkiv Surgical School, 6 (44), 47-49 [in Ukrainian].

4. Spirt, M.J. (2010). Complicated intra-abdominal infections: a focus on appendicitis and diverticulitis. Postgrad. Med., 122, 1, 39-51.

5. Kimura, W., Mizutani, M., \& Fuse, A. (2014). Problems and therapeutic strategy for emergen cy operation of the abdomen in the aged. Nippon Ronen Igakkai Zasshi, 41, 6, 660-665.

6. Petrosyan, E.A., Sergiyenko, V.I., \& Sukhinin, A.A. (2015). Sostoyaniye pro- i antioksidantnoy sistem krovi pri eksperimentalnom zhelchnom peritonite [The state of the proand antioxidant blood systems in experimental biliary peritonitis]. Byul. eksperim. biol. i med. - Bulletin of Experimental Biology and Medicine, 139, 1, 19-21 [in Russian].

7. Blot, S., \& De Waele, J.J. (2015). Critical issues in the clinical management of complicated intraabdominal infections. Drugs, 65 (12), 1611-1620.

8. Al-Malki, A.L. (2013). Oat attenuation of hyperglycemiainduced retinal oxidative stress and NF-kB activation in streptozotocin-induced diabetic rats. Evidence-Based Complementary and Alternative Medicine. Article ID 983923. DOI: http://dx.doi.org/10.1155/2013/983923

9. Lazarenko, V.A., Lipatov, V.A., Blinkov, Yu.Yu., \& Skorikov, D.V. (2008). Eksperimentalnaya model rasprostranennogo kalovogo peritonita [Experimental model of widespread fecal peritonitis]. Chelovek i yego zdorovye - Man and His Health, 4, 128-132 [in Russian].

10. Andreyeva, L.I., Kozhemyakin, L.A., \& Kishkun, A.A. (1988). Modifikatsiya metoda opredeleniya perekisey lipidov v teste $\mathrm{s}$ tiobarbiturovoy kislotoy [Modification of the method for determining lipid peroxides in a test with thiobarbituric acid]. Lab. delo - Laboratory Business, 11, 41-43 [in Russian].

11. Horiachkovskyi, O.M. (2015). Klinichna biokhimiia $v$ laboratornii diahnostytsi. Dovidkovyi posibnyk [Clinical biochemistry in laboratory diagnostics. Reference book]. Odesa: Ekolohiia [in Ukrainian].

12. Stalnaya, I.D. (1977). Sovremennyye metody $v$ biokhimii [Modern methods in biochemistry]. Moscow: Meditsina [in Russian].

Отримано 26.12.2018

Електронна адреса для листування: sepodpyatov@yahoo.com

I. YA. DZIUBANOVSKYI ${ }^{1}$, B. M. VERVEHA², S. R. PIDRUCHNA ${ }^{1}$, N. A. MELNYK ${ }^{1}$

I. Horbachevsky Ternopil State Medical University ${ }^{1}$

Danylo Halytskyi Lviv National Medical University ${ }^{2}$

\section{STATUS OF THE ANTIOXIDANT PROTECTION SYSTEM AT EXPERIMENTAL PERITONITIS AGAINST THE BACKGROUND OF DIABETES}

The aim of the work: to study the state of the antioxidant system of protection in the organism of experimental animals with acute, prevalent peritonitis modeled on the background of diabetes mellitus compared with animals with experimental acute peritonitis. Materials and Methods. 56 white rats were used in this work. Diabetes mellitus was modeled by intraperitoneal injection of Sigmal streptozotocin in a dose of $7 \mathrm{mg}$ per $100 \mathrm{~g}$ of animal weight, acute peritonitis - by administering of $0.5 \mathrm{ml}$ of $10 \%$ captured fecal suspension to the abdominal cavity of the animals under study. The indicators of antioxidant status were determined: superoxide dismutase activity of plasma, catalase activity of plasma and liver, recovered glutathione, ceruloplasmin. Terms of observation: 1 , 3, 7 days from 
the beginning of the peritonitis modeling. Blood serum and hemoglobin homogenate were used for research.

Results and Discussion. It was proved that in acute generalized peritonitis on the background of diabetes mellitus, antioxidant defense resources are exacerbated to a greater extent in comparison with the group of animals with simulated acute peritonitis. In the main group, there was a statistically significant decrease in such antioxidant parameters as ceruloplasmin (1 day - by $12.25 \%$, 3 day - by $12.11 \%$, 7 day - by $11.15 \%$ ), glutathione reduced (1 day - by $11.87 \%$, 3 day - by $10.89 \%$, 7 days - by $9.42 \%$ ), superoxide dismutase activity of the blood plasma (1 day - by $9.94 \%$, for 3 day - $13.22 \%$, 7 day - by $7.43 \%$ ), catalase activity of the liver (1 day - by $7.63 \%$, 3 day - by $19.39 \%$, 7 day - by $20.97 \%$ ), compared with a group with a simulated acute widespread peritonitis ( $<<0.05)$. In animals with experimental acute prevalent peritonitis, against the background of diabetes, protective antioxidant resources depleted to a greater extent compared to animals with a simulated acute peritonitis. Such detected inhibition of the antioxidant defense system indicates a significant depletion of the organism's protective factors in acute generalized peritonitis on the background of diabetes mellitus.

Key words: acute generalized peritonitis; diabetes mellitus; antioxidant system.

\section{И. Я. ДЗЮБАНОВСКИЙ}

гВУз “Тернопольский государственный медицинский университет имени И. Я. Горбачевского МОз Украины” Львовский национальный медицинский университет имени Данила Галицкого 2

\section{СОСТОЯНИЕ АНТИОКСИДАНТНОЙ СИСТЕМЫ ЗАЩИТЫ ПРИ ЭКСПЕРИМЕНТАЛЬНОМ ПЕРИТОНИТЕ НА ФОНЕ САХАРНОГО ДИАБЕТА}

Цель работы: изучить состояние антиоксидантной системы защиты в организме подопытных животных при смоделированном остром распространенном перитоните на фоне сахарного диабета по сравнению с животными с экспериментальным острым распространенным перитонитом.

Материалы и методы. В работе использовали 56 белых крыс. Сахарный диабет моделировали путем внутрибрюшинного введения стрептозотоцина фирмы “Sigmal” из расчета 7 мг на 100 г массы животного, острый распространенный перитонит - введением 0,5 мл 10 \% профильтрованной каловой суспензии в брюшную полость исследуемых животных. Определяли показатели антиоксидантного статуса - супероксиддисмутазную активность плазмы, каталазную активность плазмы и печени, восстановленный глутатион, церулоплазмин. Сроки наблюдения: 1, 3, 7 суток от начала моделирования перитонита. Для проведения исследований использовали сыворотку крови и гомогенат печени.

Результаты исследований и их обсуждение. Доказано, что при остром распространенномперитоните на фоне сахарного диабета в большей степени истощаются антиоксидантные ресурсы защиты по сравнению с группой животных с смоделированным острым перитонитом. В основной группе отмечалось статистически значимое снижение таких антиоксидантных показателей, как церулоплазмин (на 1 сутки - на 12,25 \%, на 3 сутки - на 12,11 \%, на 7 сутки - на 11,15 \%), восстановленный глутатион (на 1 сутки - на 11,87 \%, на 3 сутки - на 10,89 \%, на 7 сутки - на 9,42 \%), супероксиддисмутазная активность плазмы крови (на 1 сутки - на 9,94 \%, на 3 сутки - на 13, 22 \%, на 7 сутки - на 7,43 \%), каталазная активность печени (на 1 сутки - на 7,63 \%, на 3 сутки - на 19,39 \%, на 7 сутки - на 20,97 \%) по сравнению с группой с смоделированным острым распространенным перитонитом $(\mathrm{p}<0,05)$. У животных с экспериментальным острым распространенным перитонитом на фоне сахарного диабета защитные антиоксидантные ресурсы истощались в большей степени по сравнению с животными со смоделированным острым перитонитом. Такое угнетение антиоксидантной системы защиты указывает на значительное истощение факторов защиты организма при остром распространенном перитоните на фоне сахарного диабета.

Ключевые слова: острый распространенный перитонит; сахарный диабет; антиоксидантная система. 